\title{
Rhodium (II)-Catalyzed Synthesis of Tetracyclic 3,4-Fused Indoles and Dihydroindoles
}

\author{
Hongwei Qiao ${ }^{1,+}$, Jiakun Bai ${ }^{2,+}$, Mengyao Zhu ${ }^{2}$, Juanhong Gao ${ }^{2}$, Anna ${ }^{2}$, Sichun Zhang ${ }^{1, *}$ \\ and Chao $\mathrm{Li}^{2, * \mathbb{D}}$ \\ 1 Department of Chemistry, Tsinghua University, Beijing 100084, China; qhw15@mails.tsinghua.edu.cn \\ 2 State Key Laboratory of Chemical Resource Engineering, Beijing University of Chemical Technology, \\ Beijing 100029, China; jiakun_bai@163.com (J.B.); zhumengyao815@163.com (M.Z.); \\ gjuanhong@163.com (J.G.); anna@mail.buct.edu.cn (A.) \\ * Correspondence: sczhang@mail.tsinghua.edu.cn (S.Z.); lichao@mail.buct.edu.cn (C.L.) \\ + H.Q. and J.B. contributed equally to this work.
}

Received: 4 July 2020; Accepted: 6 August 2020; Published: 11 August 2020

\begin{abstract}
An efficient synthetic method of tetracyclic 3,4-fused indoles and dihydroindoles via rhodium-catalyzed (3+2) cycloaddition of N-tosyl-4-(2-phenoxyphenyl)-1,2,3-triazole was described. The aromatized xanthene derivatives can be achieved in a one-pot synthesis starting from 1-ethynyl-2-phenoxybenzene. The xanthene-based fused heterocycles were considered as the valuable fluorophore.
\end{abstract}

Keywords: rhodium catalysis; xanthene; cycloaddition; triazole; fluorophore

\section{Introduction}

Xanthene-based fluorescent dyes largely containing fluorescein and rhodamine have attracted continuous attention from researchers because of their good photophysical properties such as high absorption coefficient, high photostability, and high fluorescence quantum yield [1-8]. However, absorption and emission wavelengths of many xanthene derivatives are in the ultraviolet-visible light range below $600 \mathrm{~nm}$, which makes them unsuitable for bioimaging in living systems [9]. An important modification to the dyes is the introduction of a fused aryl ring into the xanthene skeleton. This modification brings a remarkable bathochromic shift in excitation and emission wavelengths [10]. The classic examples are Rho 101, naphthoxanthene, and SNARF-1, which exhibit much longer wavelengths than those of rhodamine and fluorescein under basic conditions (Figure 1) [11-13].

Rhodium-stabilized donor/acceptor carbenes as reactive intermediates have been widely applied in modern organic synthesis [14-26]. Among them, N-sulfonyl-1,2,3-triazole as an alternative source of carbene precursor has been used to achieve the transannulation reaction for the direct synthesis of heterocycles [27-41]. Murakami's group described a rhodium-catalyzed (3+2) annulation reaction of tricyclic 3,4-fused dihydroindoles via the corresponding 1,2,3-triazoles [42-45]. Recently, Davies et al. described a series of rhodium(II)-catalyzed intramolecular annulations of indolyl- and pyrrolyl-tethered $N$-sulfonyl-1,2,3-triazoles, including tetrahydropyrrolopyridine, tetrahydrocarboline, tetrahydro pyrrolo-[2,3- $d$ ]azepine, and azepino [4,5- $b$ ]indoles [46,47]. Based on these findings, we wondered if an analogous $\alpha$-imino carbene can be used to construct a tetracyclic aryl-fused structure from simple materials in the presence of rhodium(II) catalysts. Thus, we here described a rhodium-catalyzed intramolecular $(3+2)$ annulation to synthesize tetracyclic compounds. In addition, the reaction constituted a simple synthesis of aromatizing pyrrole-fused xanthene starting from 1-ethynyl-2-phenoxybenzene in one pot (Figure 1). 


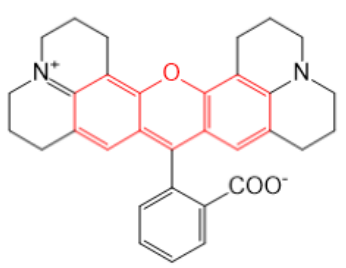

Rho 101

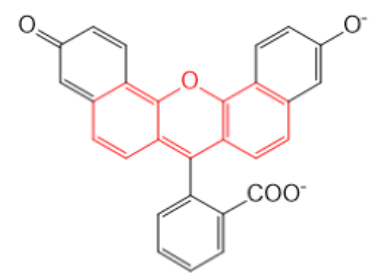

Naphthpfluorescein

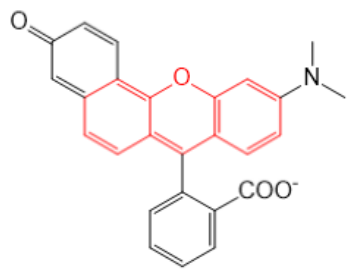

SNARF-1

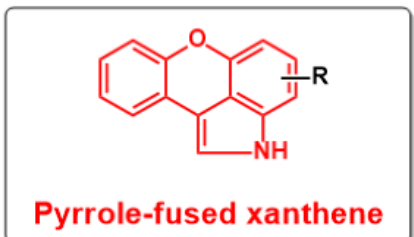

Figure 1. The fluorophores based on xanthene moiety.

\section{Results and Discussion}

Firstly, the substituted phenylboronic acids were coupled with 2-iodophenol in the presence of $\mathrm{Cu}(\mathrm{OAc})_{2}$ to provide 1-iodo-2-phenoxybenzene 1 . Iodine was converted to a trimethylsilylacetylene (TMSA) functional group using $\mathrm{PdCl}_{2}\left(\mathrm{PPh}_{3}\right)_{2}$ and $\mathrm{CuI}$ as the catalysts, and then trimethylsilyl was removed in $\mathrm{CH}_{2} \mathrm{Cl}_{2}$ solution containing $\mathrm{K}_{2} \mathrm{CO}_{3}$ to give 1-ethynyl-2-phenoxybenzene 3 [48]. Subsequently, the key intermediate $N$-tosyl-4-(2-phenoxyphenyl)-1,2,3-triazole 4 was obtained via $(3+2)$ cycloaddition of 3 with tosyl azide in the presence of CuTc. When the triazole 4 reacted with rhodium(II) octanoate dimer in toluene at $80{ }^{\circ} \mathrm{C}$ for $4 \mathrm{~h}$, the desired tetracyclic compound 5 was obtained after chromatography purification. The results delineated the scope of the (3+2) annulation reaction as shown in Scheme 1. Substrates possessing the electron-withdrawing groups smoothly reacted, and the corresponding products $\mathbf{5} \mathbf{c}-\mathbf{5 f}$ were isolated in yields ranging from $84 \%$ to $92 \%$. The unsubstituted and electron-donating group substituted substrates also successfully involved in the transformation with yields of $72 \%$ and $70 \%$, respectively ( $5 \mathbf{a}$ and $\mathbf{5 b}$ ). The stereochemistry of the tetracyclic products was analyzed by ${ }^{1} \mathrm{H}$ NMR data of $\mathbf{5 a}-\mathbf{5 f}$. $\mathrm{H}$ atoms on the methenyl group showed relatively large coupling constants $(J=14.0-15.8 \mathrm{~Hz})$. Narasaka K. et al. reported a series of cis- and trans-fused $(4,5,6,7-\eta)$-3a,7a-dihydro-3H-indoles, in which the $J$ of the cis-fused isomer was much larger than the trans- one [49]. Similarly, the coupling constants of cis-fused indole derivatives in Murakami's report were also up to $14 \mathrm{~Hz}$ [42]. Thus, the compounds $\mathbf{5 a - 5 f}$ were considered as cis-fused isomers.

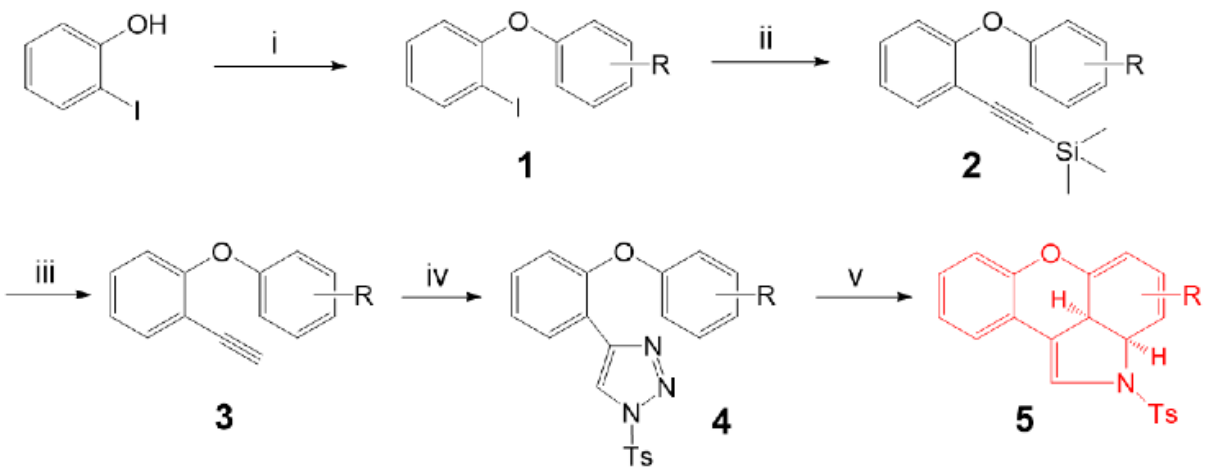

Scheme 1. Cont. 
<smiles></smiles>

5a $72 \%$<smiles>O=C(c1ccccc1)N1C=C2c3ccccc3OC3=CC(Br)=C[C@H]1[C@H]32</smiles>

5d $92 \%$

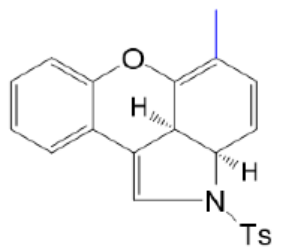

5b $70 \%$<smiles>FC1=CC=C2Oc3ccccc3C3=CN(S)[C@@H]1[C@@]23F</smiles>

5e $84 \%$<smiles>S=C(S)N1C=C2c3ccccc3OC3=CC=C(Br)[C@]32C1</smiles>

5c $85 \%$<smiles>C[C@@]12C3=CC=C(C(F)(F)F)[C@@H]1N([As])C=C2c1ccccc1O3</smiles>

5f $86 \%$

Scheme 1. Tetracycles synthesis by Rh(II) catalyst a ${ }^{a}$ Reaction conditions: (i) 2-iodophenol (1.0 equiv), substituted arylboronic acids (1.5 equiv), $\mathrm{Et}_{3} \mathrm{~N}$ (5.0 equiv), anhydrous $\mathrm{Cu}(\mathrm{OAc})_{2}$ (1.2 equiv), $\mathrm{CH}_{2} \mathrm{Cl}_{2}$, r.t., 6 h. (ii) 1 (1.0 equiv), TMSA (1.1 equiv), $\mathrm{PdCl}_{2}\left(\mathrm{PPh}_{3}\right)_{2}$ (0.02 equiv), $\mathrm{CuI}\left(0.04\right.$ equiv), $\mathrm{Et}_{3} \mathrm{~N}$, r.t., 4 h. (iii) 2 (1.0 equiv), $\mathrm{K}_{2} \mathrm{CO}_{3}$ (0.5 equiv), $\mathrm{CH}_{2} \mathrm{Cl}_{2}: \mathrm{CH}_{3} \mathrm{OH}=1: 1$, r.t., 2 h. (iv) 3 (1.0 equiv), $\mathrm{TsN}_{3}$ (1.0 equiv), $\mathrm{TcCu}\left(0.05 \text { equiv), toluene, r.t., } \mathrm{N}_{2} \text { (g), } 12 \mathrm{~h} \text {. (v) } 4 \text { (1.0 equiv), } \mathrm{Rh}_{2} \text { (oct) }\right)_{4}\left(0.02\right.$ equiv), toluene, $80{ }^{\circ} \mathrm{C}, \mathrm{N}_{2}(\mathrm{~g})$, $4 \mathrm{~h}$.

We next speculated the possible mechanism for the production of the tetracyclic 3,4-fused dihydroindole 5 (Scheme 2). An $\alpha$-diazo imino A was formed by reversible tautomerization from the corresponding triazole 4 . The intermediate $\alpha$-imino rhodium carbene $\mathbf{B}$ was obtained with the release of $\mathrm{N}_{2}(g)$ when A rapidly reacted with rhodium (II). Subsequently, the intramolecular electrophilic reaction of $\mathbf{B}$ occurred to form the zwitterionic intermediate $\mathbf{C}$. The anionic rhodium released bonding electrons, completing the second cyclization [42]. The intermediate $\mathbf{A}$ acts as a 1,3-dipole equivalent due to the nucleophilic character of the imino nitrogen. According to Davies report [47], alternatively, $\alpha$-diazoimine $\mathbf{A}$ undergoes thermal decomposition to generate free carbene $\mathbf{D}$, which could cyclopropanate an arene to give norcaradiene $\mathbf{E}$. The intermediate $\mathbf{E}$ does not have the correct geometry to undergo a $(3,5)$-sigmatropic rearrangement to give 5 .

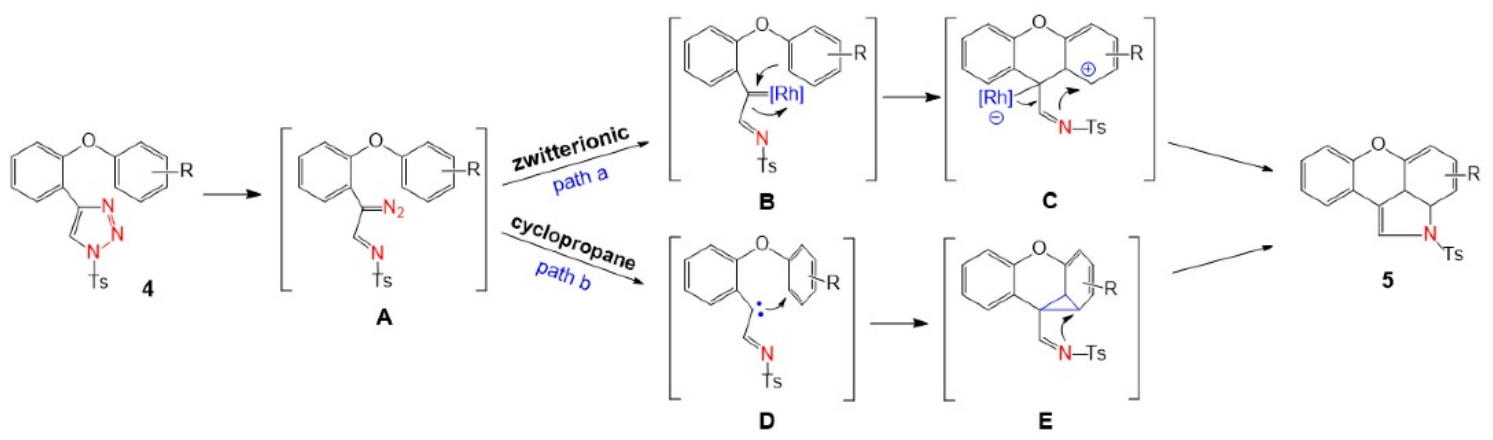

Scheme 2. Proposed mechanistic pathways.

It is noted that it was a bit hard to isolate compound 5 after the reaction because we found these tetracyclic structures were easily oxidized in air, giving the corresponding aromatized pyrrole-fused xanthene derivative 6 . According to Murakami's report, a special oxidant (such as $\mathrm{MnO}_{2}$ ) was needed to complete further oxidative aromatization [42]. However, in our case, thorough aromatization can be achieved by stirring in air for some hours. Thus, we subsequently tried to directly synthesize aromatized xanthene derivatives.

The construction of these pyrrole-fused xanthene compounds was successfully integrated into a one-pot synthesis directly from 1-ethynyl-2-phenoxybenzene 3 (Scheme 3). For example, 3g (1.0 equiv), 
tosyl azide (1.0 equiv), CuTc ( 0.05 equiv), $\left.\mathrm{Rh}_{2}(\mathrm{oct})\right)_{4}(0.02$ equiv), and toluene were mixed together in a flask. The above mixture was stirred at $25^{\circ} \mathrm{C}$ for $12 \mathrm{~h}$, during which $3 \mathrm{~g}$ was converted to the corresponding triazole $4 \mathrm{~g}$. The mixture was then stirred at $80^{\circ} \mathrm{C}$ for additional $4 \mathrm{~h}$. After being cooled to room temperature, the mixture was further stirred for $4 \mathrm{~h}$ in air. Finally, preparative thin-layer chromatography was used to afford $6 \mathrm{~g}$ in $73 \%$ yield based on $\mathbf{3 g}$. The all-in-one-pot procedure showed that the catalysts and reagents requisite in each step barely interfered with each other.

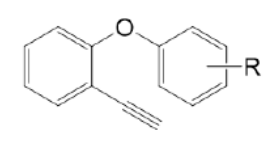

3

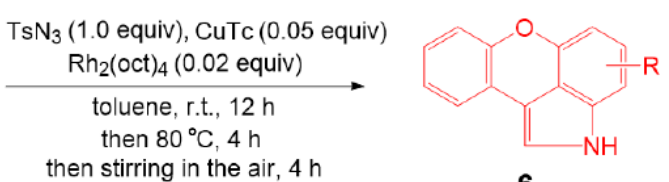

6

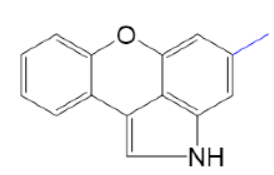

6g $60 \%$<smiles>COc1cc2c3c(c[nH]c3c1)-c1ccccc1O2</smiles>

$6 i$<smiles>COc1ccc2c3c(c[nH]c13)-c1ccccc1O2</smiles>

6h $65 \%$

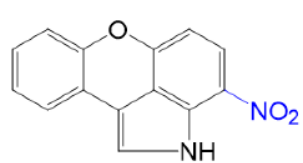

6j $73 \%$

Scheme 3. One-pot synthesis starting from 1-ethynyl-2-phenoxybenzene.

The present reaction was also used to synthesize xanthone $\mathbf{7}$ from triazole diaryl ether $\mathbf{4}$, as shown in Scheme 4. When $\mathrm{N}, \mathrm{N}$-diethyl substituted $4 \mathbf{k}$ in toluene and was catalyzed by $\mathrm{Rh}_{2}(\mathrm{oct})_{4}$ at $80{ }^{\circ} \mathrm{C}$, no pyrrole-fused xanthene skeleton was obtained. Instead, the corresponding xanthone $7 \mathbf{k}$ was obtained in $75 \%$ isolated yield. After the first cycloaddition to form intermediate $\mathbf{C}$, the strong electron-donating substituent $\mathrm{N}\left(\mathrm{C}_{2} \mathrm{H}_{5}\right)_{2}$ weakened the electropositivity of the allyl position, which was unfavorable for the second cyclization with the imino nitrogen. The tosyl amide was further oxidized to a carbonyl group in air, affording a stable xanthone derivative. Similarly, the substrate $4 \mathbf{l}^{\prime}$ with an intense electron-donor group diethyl amine also underwent a single cycloaddition reaction to give xanthone $7 \mathbf{1}^{\prime}$ in $80 \%$ yield. Shen et al. reported a similar process for the synthesis of $N$-methyl acridone derivatives [50]. The triazole intermediate was converted to acridone by rhodium catalysis via a single cycloaddition.

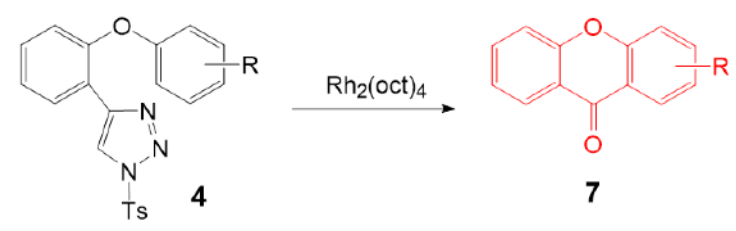

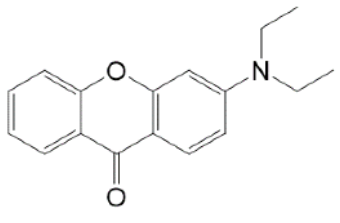

$7 \mathbf{k} 75 \%$<smiles>CCN(CC)c1ccc2c(=O)c3ccc([N+](=O)[O-])cc3oc2c1</smiles>

7l' $80 \%$

Scheme 4. Synthesis of $9 \mathrm{H}-x a n t h e n-9-$ one $^{\mathrm{a}}$. 
In addition, a special case of the rhodium catalysis process was obtained for the $O$-methoxy substrate. The (3+2) annulation reaction of $N$-tosyl-4-(2-phenoxyphenyl)-1,2,3-triazole $4 \mathrm{~m}$ took place by $\mathrm{Rh}_{2}(\mathrm{oct})_{4}$ in toluene under the same conditions. However, oxidative aromatization directly occurred during the process of annulation, and also the $O$-methoxy group was simultaneously removed, affording the aromatized pyrrole-fused xanthene 8 with 78\% yield (Scheme 5). Due to the rotatable C-O bond in diaryl ether, the carbenoid carbon of $\mathbf{B}$ is electrophilic to react with methoxyl site. When intramolecular attack of the phenyl ring in the methoxyl site occurs to furnish the zwitterionic intermediate, methoxyl as a good leaving group could be removed. In the tested substrates, only $O$-methoxy-substituted triazole could be aromatized, retaining a tosyl group in the oxidation process.

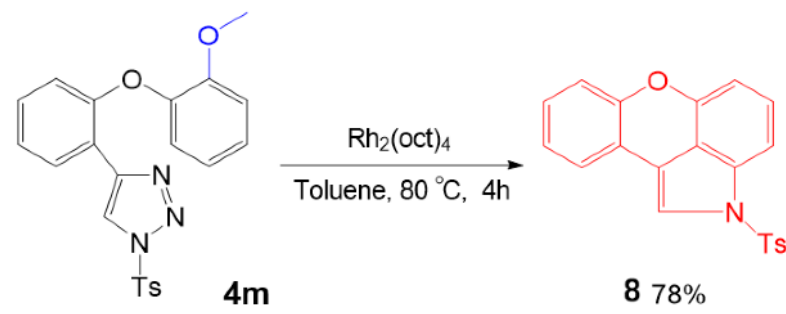

Scheme 5. Special oxidative aromatization reaction of 4-(2-phenoxyphenyl)-1,2,3-triazole.

Encouraged by the straightforward synthetic pathway described above, we tried to investigate the fluorescent properties of the pyrrole-fused xanthene skeleton. The excitation $\left(\lambda_{\text {ex }}\right)$ and emission $\left(\lambda_{\mathrm{em}}\right)$ wavelengths of the typical structures were tested as shown in Table 1 . The unaromatized 5a showed spectral characteristics that were comparable to rhodamine with $\lambda_{\mathrm{em}}=443 \mathrm{~nm}$ and $\Phi=0.31$. The entirely aromatized structures via oxidation, such as $\mathbf{6 g} \mathbf{- 6} \mathbf{j}$, exhibited longer emission wavelengths at 471, 480, and $552 \mathrm{~nm}$, respectively. When the substituent was an electron-withdrawing $\mathrm{NO}_{2}$ group, the fluorescent properties including emission wavelength and quantum yield remarkably increased. Two xanthone-based products, $7 \mathbf{k}$ and $7 \mathbf{1}^{\prime}$, were also analyzed, giving $\lambda_{\mathrm{em}}=426 \mathrm{~nm}$ and $\lambda_{\mathrm{em}}=457 \mathrm{~nm}$ with acceptable quantum yields, respectively. These results indicated that the pyrrole-fused xanthene or imino-modified derivatives in pyrrole were used as a potential fluorophore to develop new applications.

Table 1. Fluorescent properties of the typical structures ${ }^{a}$.

\begin{tabular}{|c|c|c|c|c|}
\hline Comp. & Solvent & $\lambda_{\mathrm{ex}}(\mathrm{nm})$ & $\lambda_{\mathrm{em}}(\mathrm{nm})$ & Quantum Yield $(\Phi)$ \\
\hline $5 a$ & $\mathrm{CH}_{2} \mathrm{Cl}_{2}$ & 388 & 443 & 0.31 \\
\hline $6 \mathrm{~g}$ & $\mathrm{CH}_{3} \mathrm{CN}$ & 370 & 471 & 0.45 \\
\hline $6 \mathrm{~h}$ & $\mathrm{CH}_{2} \mathrm{Cl}_{2}$ & 327 & 480 & 0.38 \\
\hline $6 j$ & DMSO & 436 & 552 & 0.52 \\
\hline $7 \mathrm{k}$ & DMSO & 355 & 426 & 0.41 \\
\hline $71^{\prime}$ & DMSO & 355 & 457 & 0.35 \\
\hline
\end{tabular}

a See SI Figure S1 for details of emission $\left(\lambda_{\mathrm{em}}\right)$ wavelength and quantum yield $(\Phi)$ for the typical compounds.

\section{Materials and Methods}

\subsection{Materials}

Unless specifically mentioned, all chemicals were purchased from Beijing Ouhe Technology Co. Ltd., Beijing, China, or J\&K Scientific Ltd., Beijing, China, and used without further purification.

\subsection{Typical Procedure for the Synthesis of Triazole 4}

A mixture of $3 \mathrm{a}(1.32 \mathrm{~g}, 6.80 \mathrm{mmol})$ and copper(I) thiophene-2-carboxylate $(64.79 \mathrm{mg}, 0.34 \mathrm{mmol})$ was dissolved in dry toluene $(30 \mathrm{~mL})$. $\mathrm{TsN}_{3}(1.38 \mathrm{~mL}, 6.80 \mathrm{mmol})$ was added via syringe, and the solution was stirred at room temperature for $12 \mathrm{~h}$ under a nitrogen atmosphere. The crude product was 
further recrystallized from hexane/ $\mathrm{CH}_{2} \mathrm{Cl}_{2}$ (15:1) to yield the final pure $4 \mathbf{a}$ as a white solid (77\% yield). Compounds $\mathbf{4 b}-\mathbf{f}$ were synthesized using a similar route according to $4 \mathbf{a}$.

\subsection{Tetracycle 5 Synthesis by Rh(II) Catalyst}

Compound $4 \mathrm{a}(0.65 \mathrm{~g}, 1.66 \mathrm{mmol})$ and $\mathrm{Rh}_{2}(\mathrm{oct})_{4}(25.86 \mathrm{mg}, 0.03 \mathrm{mmol})$ were dissolved in dry toluene $(10 \mathrm{~mL})$ in a Schlenk tube. The solution was heated for $4 \mathrm{~h}$ at $80^{\circ} \mathrm{C}$. Then, the mixture was evaporated under vacuum to give the crude product, which was purified by silica gel column chromatography hexane/ethyl acetate (20:1) to give $\mathbf{5 a}$ ( $72 \%$ yield). Compounds $\mathbf{5} \mathbf{b}-\mathbf{f}$ were synthesized using a similar route according to $5 \mathbf{a}$.

\subsection{One-Pot Synthesis of $\mathbf{6}$ Starting from 1-ethynyl-2-phenoxybenzene}

Compound $3 \mathrm{~g}(0.8 \mathrm{~g}, 3.84 \mathrm{mmol}), \mathrm{TsN}_{3}(0.76 \mathrm{~g}, 3.84 \mathrm{mmol}), \mathrm{CuTc}(36.62 \mathrm{mg}, 0.19 \mathrm{mmol})$, and $\mathrm{Rh}_{2}(\mathrm{oct})_{4}(59.82 \mathrm{mg}, 76.83 \mu \mathrm{mol})$ were dissolved in dry toluene $(10 \mathrm{~mL})$ in a Schlenk tube. The solution was stirred at room temperature for $12 \mathrm{~h}$ and then heated to $80^{\circ} \mathrm{C}$ for $4 \mathrm{~h}$. After being cooled to room temperature, the solution was further stirred at room temperature for $4 \mathrm{~h}$ in air. Then, the mixture was evaporated under vacuum to give the crude product, which was purified by silica gel column chromatography hexane/ethyl acetate (20:1) to give $\mathbf{6 g}$ (60\% yield). Compounds $\mathbf{6 h}-\mathbf{j}$ were synthesized using a similar route according to $6 \mathrm{~g}$.

\subsection{Synthesis of 9H-xanthen-9-one and Special Oxidative Aromatization Reaction of} 4-(2-phenoxyphenyl)-1,2,3-triazole

Compounds $\mathbf{7 k}, \mathbf{7 \mathbf { l } ^ { \prime }}$, and $\mathbf{8}$ were synthesized using a similar route according to $\mathbf{5 a}$.

\subsection{Calculation of the Fluorescence Quantum Yield}

The quantum yield of the fluorophore was calculated according to Equation (1):

$$
\varphi_{U}=\varphi_{S}\left(\frac{F_{U}}{F_{S}}\right)\left(\frac{A_{S}}{A_{U}}\right)\left(\frac{\eta_{U}^{2}}{\eta_{S}^{2}}\right)
$$

where $\varphi_{s}$ is the quantum yield of the standard, $F$ is the area under the emission spectra, $A$ is the absorbance at the excitation wavelength, and $\eta$ is the refractive index of the solvent used. $U$ subscript denotes unknown, and $S$ means standard. Rhodamine B was chosen as the standard.

\section{Conclusions}

In conclusion, we have described the intramolecular (3+2) annulation of $\alpha$-imino rhodium carbene complexes to construct tetracyclic 3,4-fused indoles and dihydroindoles. Of note is that the reaction is illustrated by its successful integration into a one-pot synthesis directly from 1-ethynyl2-phenoxybenzene, giving a series of xanthene derivatives. Xanthenes are important in fluorescent dye and medicinal chemistry, and we think that the current approach is an appealing choice for the construction of molecular libraries for diversity-oriented synthesis.

Supplementary Materials: The following are available online at http://www.mdpi.com/2073-4344/10/8/920/s1. NMR and HRMS data of compounds 4-8; ${ }^{1} \mathrm{H}$ NMR, ${ }^{13} \mathrm{C}$ NMR, and HRMS spectra of compounds 4-8; fluorescence spectra of $5 \mathrm{a}, 6 \mathrm{~g}, 6 \mathrm{~h}, 6 \mathbf{j}, 7 \mathrm{k}$, and $7 \mathrm{l}^{\prime}$.

Author Contributions: Performed the experiments, H.Q. and J.B.; wrote the manuscript, S.Z. and C.L.; analyzed the characterization of compounds, M.Z., J.G., and A. All authors have read and agreed to the published version of the manuscript.

Funding: This research was funded by the National Natural Science Foundation of China $(21974078,21672021$, and 21572018).

Conflicts of Interest: The authors declare no conflict of interest. 


\section{References}

1. Lavis, L.D.; Rutkoski, T.J.; Raines, R.T. Tuning the pKa of Fluorescein to Optimize Binding Assays. Anal. Chem. 2007, 79, 6775. [CrossRef] [PubMed]

2. Yan, F.Y.; Fan, K.Q.; Bai, Z.J.; Zhang, R.Q.; Zu, F.L.; Xu, J.X.; Li, X. Fluorescein applications as fluorescent probes for the detection of analytes. Trend. Anal. Chem. 2017, 97, 15. [CrossRef]

3. Beija, M.; Afonso, C.A.M.; Martinho, J.M.G. Synthesis and applications of Rhodamine derivatives as fluorescent probes. Chem. Soc. Rev. 2009, 38, 2410. [CrossRef] [PubMed]

4. Lavis, L.D. Teaching Old Dyes New Tricks: Biological Probes Built from Fluoresceins and Rhodamines. Annu. Rev. Biochem. 2017, 86, 825. [CrossRef]

5. Wang, L.; Du, W.; Hu, Z.; Uvdal, K.; Li, L.; Huang, W. Hybrid Rhodamine Fluorophores in the Visible/NIR Region for Biological Imaging. Angew. Chem. Int. Ed. 2019, 58, 14026. [CrossRef]

6. Lavis, L.D.; Raines, R.T. Bright Ideas for Chemical Biology. ACS Chem. Biol. 2008, 3, 142. [CrossRef]

7. Kushida, Y.; Nagano, T.; Hanaoka, K. Silicon-substituted xanthene dyes and their applications in bioimaging. Analyst 2015, 140, 685. [CrossRef]

8. Derayea, S.M.; Nagy, D.M. Application of a xanthene dye, eosin Y, as spectroscopic probe in chemical and pharmaceutical analysis; a review. Rev. Anal. Chem. 2018, 37, 20170020. [CrossRef]

9. Zhao, M.; Guo, Y.S.; Xu, W.N.; Zhao, Y.F.; Xie, H.Y.; Li, H.J.; Chen, X.F.; Zhao, R.S.; Guo, D.S. Far-red to near-infrared fluorescent probes based on silicon-substituted xanthene dyes for sensing and imaging. Trend. Anal. Chem. 2020, 122, 115704. [CrossRef]

10. Zheng, H.; Zhan, X.Q.; Bian, Q.N.; Zhang, X.J. Advances in modifying fluorescein and rhodamine fluorophores as fluorescent chemosensors. Chem. Commun. 2013, 49, 429. [CrossRef] [PubMed]

11. Lee, L.G.; Berry, G.M.; Chen, C.H. Vita blue: A new 633-nm excitable fluorescent dye for cell analysis. Cytometry 1989, 10, 151. [CrossRef] [PubMed]

12. Whitaker, J.E.; Haugland, R.P.; Prendergast, F.G. Spectral and photophysical studies of benzo[c]xanthene dyes: Dual emission pH sensors. Anal. Biochem. 1991, 194, 330. [CrossRef]

13. Liu, J.; Diwu, Z.; Leung, W.Y. Synthesis and photophysical properties of new fluorinated benzo[c]xanthene dyes as intracellular pH indicators. Bioorg. Med. Chem. Lett. 2001, 11, 2903. [CrossRef]

14. Gu, J.; Du, W.; Chen, Y. Combined Asymmetric Aminocatalysis and Carbene Catalysis. Synthesis 2015, 47,3451 .

15. Mahrwald, R. Organocatalytic methods for C-C bond formation. Drug Discov. Today 2013, 10, 29. [CrossRef] [PubMed]

16. Meng, J.; Wen, M.; Zhang, S.W.; Pan, P.W.; Yu, X.X.; Deng, W.P. Unexpected O-H Insertion of Rhodium-Azavinylcarbenes with N-Acylhydrazones: Divergent Synthesis of 3,6-Disubstituted- and 3,5,6-Trisubstituted-1,2,4-Triazines. J. Org. Chem. 2017, 82, 1676. [CrossRef]

17. Lavigne, F.; Kazzi, A.E.; Escudie, Y.; Maerten, E.; Kato, T.; Saffon-Merceron, N.; Branchadell, V.; Cossio, F.P.; Baceiredo, A. Azavinylidenephosphoranes: A class of cyclic push-pull carbenes. Chem. Eur. J. 2014, 20, 12528. [CrossRef]

18. Arduengo, A.J.; Dias, H.V.; Harlow, R.L. Electronic stabilization of nucleophilic carbenes. J. Am. Chem. Soc. 1992, 114, 5530. [CrossRef]

19. Chuprakov, S.; Malik, J.A.; Zibinsky, M.; Fokin, V.V. Catalytic Asymmetric C-H Insertions of Rhodium(II) Azavinyl Carbenes. J. Am. Chem. Soc. 2011, 133, 10352. [CrossRef]

20. He, J.; Shi, Y.P.; Cheng, W.L.; Man, Z.M.; Yang, D.D.; Li, C.Y. Rhodium-Catalyzed Synthesis of 4-Bromo-1,2-dihydroisoquinolines: Access to Bromonium Ylides by the Intramolecular Reaction of a Benzyl Bromide and an $\alpha$-Imino Carbene. Angew. Chem. Int. Ed. 2016, 55, 4557. [CrossRef]

21. Wang, Y.H.; Lei, X.Q.; Tang, Y.F. Rh(II)-catalyzed cycloadditions of 1-tosyl 1,2,3-triazoles with 2H-azirines: Switchable reactivity of Rh-azavinylcarbene as [2C]- or aza-[3C]-synthon. Chem. Commun. 2015, 51, 4507. [CrossRef] [PubMed]

22. Stéphane, B.; Dagorne, S. Group 1 and 2 and Early Transition Metal Complexes Bearing N-Heterocyclic Carbene Ligands: Coordination Chemistry, Reactivity, and Applications. Chem. Rev. 2014, 114, 8747.

23. Pal, K.; Hoque, A.; Volla, C.M.R. Rh-Catalyzed Denitrogenative Reaction of N-Sulfonyl-1,2,3-triazoles with Isatoic Anhydrides and Oxadiazolones. Chem. Eur. J. 2018, 24, 2558. [CrossRef] [PubMed] 
24. Selander, N.; Worrell, B.T.; Fokin, V.V. Ring Expansion and Rearrangements of Rhodium(II) Azavinyl Carbenes. Angew. Chem. Int. Ed. 2012, 51, 13054. [CrossRef]

25. Selander, N.; Worrell, B.T.; Chuprakov, S.; Velaparthi, S.; Fokin, V.V. Arylation of Rhodium(II) Azavinyl Carbenes with Boronic Acids. J. Am. Chem. Soc. 2012, 134, 14670. [CrossRef]

26. Jung, D.J.; Jeon, H.J.; Kim, J.H.; Kim, Y.; Lee, S. DMF as a Source of Oxygen and Aminomethine: Stereoselective 1,2-Insertion of Rhodium(II) Azavinyl Carbenes into the $\mathrm{C}=\mathrm{O}$ Bond of Formamides for the Synthesis of cis-Diamino Enones. Org. Lett. 2014, 16, 2208. [CrossRef]

27. Chattopadhyay, B.; Gevorgyan, V. Rh-catalyzed transannulation of N-tosyl-1,2,3-triazoles with terminal alkynes. Org. Lett. 2011, 13, 3746. [CrossRef]

28. Zibinsky, M.; Fokin, V.V. Sulfonyl-1,2,3-Triazoles: Convenient Synthones for Heterocyclic Compounds. Angew. Chem. Int. Ed. 2013, 52, 1507. [CrossRef]

29. Kubiak, R.W.; Mighion, J.D.; Wilkerson-Hill, S.M.; Alford, J.S.; Yoshidomi, T.; Davies, H.M.L. Enantioselective Intermolecular C-H Functionalization of Allylic and Benzylic sp3 C-H Bonds Using N-Sulfonyl-1,2,3-triazoles. Org. Lett. 2016, 18, 3118. [CrossRef]

30. Alford, J.S.; Davies, H.M.L. Expanding the scope of donor/acceptor carbenes to N-phthalimido donor groups: Diastereoselective synthesis of 1-cyclopropane $\alpha$-amino acids. Org. Lett. 2012, 14, 6020. [CrossRef]

31. Khaidarov, A.R.; Rostovskii, N.V.; Zolotarev, A.A.; Khlebnikov, A.F.; Novikov, M.S. Synthesis of 1-(2-Aminovinyl)indoles and 1,3'-Biindoles by Reaction of 2,2-Diaryl-Substituted 2H-Azirines with $\alpha$-Imino Rh(II) Carbenoids. J. Org. Chem. 2019, 84, 3743. [CrossRef] [PubMed]

32. Chuprakov, S.; Hwang, F.W.; Gevorgyan, V. Rh-catalyzed transannulation of pyridotriazoles with alkynes and nitriles. Angew. Chem. Int. Ed. 2007, 46, 4757. [CrossRef] [PubMed]

33. Horneff, T.; Chuprakov, S.; Chernyak, N. Rhodium-Catalyzed Transannulation of 1,2,3-Triazoles with Nitriles. J. Am. Chem. Soc. 2008, 130, 14972. [CrossRef] [PubMed]

34. Garlets, Z.J.; Davies, H.M.L. Harnessing the $\beta$-Silicon Effect for Regioselective and Stereoselective Rhodium(II)-Catalyzed C-H Functionalization by Donor/Acceptor Carbenes Derived from 1-Sulfonyl1,2,3-triazoles. Org. Lett. 2018, 20, 2168. [CrossRef] [PubMed]

35. Pan, X.H.; Jiang, P.; Jia, Z.H.; Xu, K.; Cao, J.; Chen, C.; Shen, M.H.; Xu, H.D. Expedient catalytic construction of azabicyclo[4.1.0]/[5.1.0] carbaldehydes via intramolecular cyclopropanation. Tetrahedron 2015, 71, 5124. [CrossRef]

36. Alcaide, B.; Almendros, P.; Fernandez, I.; Campo, T.M.; Palop, G.; Toledano-Pinedo, M.; Delgado-Martinez, P. Chemoselectivity Switching in the Rhodium-Catalyzed Reactions of 4-Substituted-1-sulfonyl-1,2,3-triazoles with Allenols: Noticeable Differences between 4-Acyl- and 4-Aryl-Triazoles. Adv. Synth. Catal. 2019, 361, 1160. [CrossRef]

37. Bora, P.P.; Luo, Z.L.; Chen, L. Rh(II)-catalyzed intramolecular dearomatizing annulation of N-sulfonyl1,2,3-triazoles: Synthesis of polycyclic spiroindolines. Tetrahedron 2016, 72, 1467. [CrossRef]

38. Chuprakov, S.; Worrell, B.T.; Selander, N.; Sit, R.K.; Fokin, V.V. Stereoselective 1,3-Insertions of Rhodium(II) Azavinyl Carbenes. J. Am. Chem. Soc. 2014, 136, 195. [CrossRef]

39. Grimster, N.; Zhang, L.; Fokin, V.V. Synthesis and Reactivity of Rhodium(II) N-Triflyl Azavinyl Carbenes. J. Am. Chem. Soc. 2010, 132, 2510. [CrossRef]

40. Miura, T.; Biyajima, T.; Fujii, T.; Murakami, M. Synthesis of $\alpha$-amino ketones from terminal alkynes via rhodium-catalyzed denitrogenative hydration of N-sulfonyl-1,2,3-triazoles. J. Am. Chem. Soc. 2012, 134, 194. [CrossRef]

41. Jeon, H.J.; Jung, D.J.; Kim, J.H.; Kim, Y.; Bouffard, J.; Lee, S. From Triazoles to Imidazolines through the Sequential N-H Insertion of $\alpha$-Imino Rhodium-Carbenes into $\beta$-Enamino Esters/Enamine-Imine Tautomerization/Conjugate Addition Cascade. J. Org. Chem. 2014, 79, 9865. [CrossRef] [PubMed]

42. Miura, T.; Funakoshi, Y.; Murakami, M. Intramolecular Dearomatizing [3+2] Annulation of $\alpha$-Imino Carbenoids with Aryl Rings Furnishing 3,4-Fused Indole Skeletons. J. Am. Chem. Soc. 2014, 136, 2272. [CrossRef]

43. Miura, T.; Zhao, Q.; Murakami, M. Selective Functionalization of Aromatic C(sp2)-H Bonds in the Presence of Benzylic C(sp3)-H Bonds by Electron-Deficient Carbenoids Generated from 4-Acyl-1-Sulfonyl-1,2,3-Triazoles. Angew. Chem. Int. Ed. 2017, 56, 16645. [CrossRef] [PubMed] 
44. Miura, T.; Funakoshi, Y.; Fujimoto, Y.; Nakahashi, J.; Murakami, M. Facile Synthesis of 2,5-Disubstituted Thiazoles from Terminal Alkynes, Sulfonyl Azides, and Thionoesters. Org. Lett. 2015, 17, 2454. [CrossRef] [PubMed]

45. Miura, T.; Fujimoto, Y.; Funakoshi, Y.; Murakami, M. A Reaction of Triazoles with Thioesters to Produce $\beta$-Sulfanyl Enamides by Insertion of an Enamine Moiety into the Sulfur-Carbonyl Bond. Angew. Chem. Int. Ed. 2015, 54, 9967. [CrossRef] [PubMed]

46. Fu, L.; Davies, H.M.L. Scope of the Reactions of Indolyl- and Pyrrolyl-Tethered N-Sulfonyl-1,2,3-triazoles: Rhodium(II)-Catalyzed Synthesis of Indole- and Pyrrole-Fused Polycyclic Compounds. Org. Lett. 2017, 19, 1504. [CrossRef]

47. Wilkerson-Hill, S.M.; Haines, B.E.; Musaev, D.G.; Davies, H.M.L. Synthesis of [3a,7a]-Dihydroindoles by a Tandem Arene Cyclopropanation/3,5-Sigmatropic Rearrangement Reaction. J. Org. Chem. 2018, 83, 7939. [CrossRef]

48. Xu, Y.P.; Hu, R.H.; Cai, M.Z. A facile synthesis of terminal arylacetylenes via Sonogashira coupling reactions catalyzed by MCM-41-supported mercapto palladium(0) complex. Chin. Chem. Lett. 2008, 19, 783. [CrossRef]

49. Tanaka, K.; Yukimura, N.; Narasaka, K. Radical cyclization of O-pentafluorobenzoyloximes having a (cyclohexadiene)Fe(CO)3 moiety. Bull. Chem. Soc. Jpn. 2004, 77, 575. [CrossRef]

50. Xu, H.D.; Pan, Y.P.; Ren, X.T.; Zhang, P.; Shen, M.H. A one-pot construction of acridones by rhodium catalyzed reaction of N-phenyl-2-(1-sulfonyl-1H-1,2,3-triazol-4-yl)aniline. Tetrahedron Lett. 2015, 56, 6734. [CrossRef]

(C) 2020 by the authors. Licensee MDPI, Basel, Switzerland. This article is an open access article distributed under the terms and conditions of the Creative Commons Attribution (CC BY) license (http://creativecommons.org/licenses/by/4.0/). 